\title{
JCEIB
}

Open Access; Volume 1 pp. 42-56; March2017

CUniversiti Malaysia Pahang Publisher

DOI: https://doi.org/10.15282/JCEIB-V1-07.31/3/2017/1.1.1

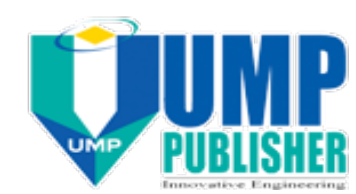

\section{FACTORIAL ANALYSIS ON PROCESSING FACTORS FOR NITROGEN, PHOSPHORUS AND POTASSIUM CONTENTS IN MUSHROOM WASTE}

\author{
Norazwina Zainol*, Muhammad Faiz Mohamed Ameen, Sunarti Abdul Rahman, \\ Muhammad Adib Rinalto, Nur Syahirah Muhammad Nor \\ Faculty of Chemical \& Natural Resources Engineering, \\ Universiti Malaysia Pahang, 26300 Gambang, Kuantan, Pahang, Malaysia \\ * Corresponding author: E-mail: azwina@ump.edu.my \\ Tel.: +60192719331 Fax: +6095492889
}

\begin{abstract}
The agriculture industry relies heavily on the use of bio-fertilizer and the main components in bio-fertilizer are nitrogen $(\mathrm{N})$, phosphorous $(\mathrm{P})$, and potassium $(\mathrm{K})$. Thus, a study was conducted to identify the $\mathrm{N}, \mathrm{P}$, and $\mathrm{K}$ contents in mushroom waste (MW). These components are numerous building blocks that plants need for healthy growth. Therefore, by increasing the $\mathrm{N}, \mathrm{P}$ and $\mathrm{K}$ contents in $\mathrm{MW}$, it can be utilized to produce high and better quality of bio-fertilizer. Five independent factors, i.e., aging of waste (fresh 0 day $\&$ aged 14 days), waste $\mathrm{pH}(7 \& 8.5)$, composition [MW only \& mixture of MW \& spent medium (SM)], technique of drying (oven $50{ }^{\circ} \mathrm{C} \&$ sunlight), and MW size (powder \& cut) were the affecting factors on N, P, and K contents in MW. A $2^{5-1}$ fractional factorial design was used to investigate the effect of the independent factors as well as the interaction factors on the $\mathrm{N}, \mathrm{P}$, and $\mathrm{K}$ contents. The $\mathrm{N}, \mathrm{P}$, and $\mathrm{K}$ contents were measured using $\mathrm{HACH}$ spectrophotometer. The objective of this research is to identify the best combination of processing factors. Some of the independent factors were shown to have significant effects on the N, P and K contents. The results showed that the most significant factor in $\mathrm{N}$ content are MW size and aging of waste, while for $\mathrm{P}$ and $\mathrm{K}$ contents are technique of drying and MW size. The best condition was identified to maximize the amount of N, P, and K contents in MW. The identified conditions were the MW aged for 7 days, MW size at powder form, waste $\mathrm{pH}$ at 7, drying under sun light and the composition MW only. Based on the proposed best condition the N (12.08 mg/L), P (3.04 $\mathrm{mg} / \mathrm{L})$, and $\mathrm{K}(8.09 \mathrm{mg} / \mathrm{L})$ contents were achieved. The results show that fractional factorial design was suitable in investigating the effect of a large number of factors with a minimum number of experiments.
\end{abstract}

Keywords: Bio-fertilizer; mushroom waste (MW); two level factorial analysis (TLFA); $\mathrm{N}, \mathrm{P}$ and $\mathrm{K}$ contents

\subsection{INTRODUCTION}

Most mushroom waste (MW) in Malaysia is mainly from grey oyster mushroom and it has a good source of protein, vitamins, and minerals. Besides, it is also used as food and medicine (Caglarirmak, 2007). Bio-fertilizer is the substance containing living microorganisms where it increases the productivity and availability of primary nutrients when applied to soil (Chatterjee et al., 2006). It has significant contribution in the growth 
and yield of the plants (Chandrasekar et al., 2005). Furthermore, it able to fix atmospheric nitrogen in the available form for plants either by living freely in the soil or being associated symbiotically with plants (Karami et al., 2011).

Apart from that, chemical fertilizers pose a health hazard and a microbial population problem in soil besides beings quite expensive and making the cost of production high. In such a situation, the bio-fertilizers play a major role (Mahdi et al., 2010). Several authors such as Fawzy et al. (2007) and Ahmad et al. (2008) concentrated on the quality and influence on the growth of plants by applying the bio-fertilizer in farming system. Since MW has high levels of nutrients such N, P, K and high amounts of organic matter (Peyvast et al., 2007a; Peyvast et al., 2008b and Shabani et al., 2011) it be superior to the farmyard. Based on the nutrient contents in MW, it could be utilized as bio-fertilizer by maximising the $\mathrm{N}, \mathrm{P}$ and $\mathrm{K}$ contents.

Therefore, the study conducted focus on the factors contributing on $\mathrm{N}, \mathrm{P}$ and $\mathrm{K}$ contents in MW. The factors that been selected in this research were aging of waste, waste $\mathrm{pH}$, composition, technique of drying and MW size. Two level factorial analysis (TLFA) factorial design used for factor analysis. The aims of TLFA was to study a response (output variable) that influenced by several independent factors (input variables). Besides, it identifies the factors that have the highest contribution on $\mathrm{N}, \mathrm{P}$ and $\mathrm{K}$ contents. Two-level analysis is very important because it quickly filters out unwanted effects. Thus, the attention can then be focused on the important ones.

\section{Analysis method}

\subsection{MATERIALS AND METHODS}

The MW samples were analyzed to determine the N, P, and $\mathrm{K}$ contents using $\mathrm{HACH}$ spectrophotometer. The methods and chemicals used during the analyses were listed in the Table 1.

Table 1: Method and chemical for N, $\mathrm{P}$ and $\mathrm{K}$ analysis

\begin{tabular}{ccc}
\hline Method & Chemical & $\begin{array}{c}\text { Component } \\
\text { analysed }\end{array}$ \\
\hline $\begin{array}{c}\text { Persulfate digestion } \\
\text { method }\end{array}$ & $\begin{array}{c}\text { Total nitrogen persulfate reagent powder } \\
\text { pillow, total nitrogen hydroxide reagent } \\
\text { vials, TN reagent A powder pillow and } \\
\text { TN reagent B powder pillow }\end{array}$ & $\mathrm{N}$ \\
$\begin{array}{c}\text { Molybdovanadate } \\
\text { method with acid } \\
\text { persulfate digestion }\end{array}$ & $\begin{array}{c}\text { Total phosphorus test 'N' tube vial, } \\
\text { molybdovanadate reagent and 1.54 N } \\
\text { sodium hydroxide }\end{array}$ & $\mathrm{P}$ \\
$\begin{array}{c}\text { Tetraphenylborate } \\
\text { method }\end{array}$ & $\begin{array}{c}\text { Potassium persulfate powder pillow, } \\
\text { potassium 1 reagent pillow, potassium 2 } \\
\text { reagent pillow and potassium 3 reagent } \\
\text { pillow }\end{array}$ & $\mathrm{K}$ \\
& & \\
\hline
\end{tabular}




\section{Mushroom Waste Sample collection and preparation}

In this study, the MW samples from grey oyster mushrooms (Pleurotus sajor-caju spp) were collected from Rozeriya Enterprise in Kuala Krai, Kelantan, Malaysia. The samples were collected after the mushroom harvesting time.

\section{Experimental design setup}

Five factors were chosen and divided to categorical and numerical factors. There were three categorical factors, namely composition of MW, technique of drying, and MW size. The other two factors were numerical factors which were aging of waste and waste $\mathrm{pH}$. The effects of these factors were explored by using a $2^{5-1}$ fractional factorial design. The experimental design for factorial analysis was performed by using Design Expert software V.7. The two-level factorial design was used in this study. This method was used to analyze five factors that were found to affect the N, P and $\mathrm{K}$ contents. Table 2 lists the design factors and levels coded as -1 (low level) and +1 (high level). The low level indicates the lowest range of the factors and high level indicates the highest range of the factors. The 16 runs of experiments were performed in this study. The responses of the experimental design were $\mathrm{N}, \mathrm{P}$ and $\mathrm{K}$ contents measured using $\mathrm{HACH}$ spectrophotometer. The experimental data were analyzed using analysis of variance (ANOVA) performed using Design Expert software V7.

Table 2: $2^{5-1}$ Fractional Factor Design Matrix

\begin{tabular}{lcc}
\hline \multirow{1}{*}{ Factor } & \multicolumn{2}{c}{ Level } \\
\cline { 2 - 3 } & -1 & +1 \\
\hline Aging of MW & 0 day - fresh & 7 days \\
MW size & Cut & Powder \\
pH & 7 & 8 \\
Technique of drying & Sunlight & Oven $50^{\circ} \mathrm{C}$ \\
Composition & MW & Mix MW and SM (spent media) \\
\hline
\end{tabular}

\subsection{RESULTS AND DISCUSSION}

\section{Screening of factors affecting on the $N, P$ and $K$ contents}

The screening of the factors that contributed on $\mathrm{N}, \mathrm{P}$ and $\mathrm{K}$ content was carried out through $2^{5-1}$ fractional designs as shown in Table 3 . This was to categorize the degree of the effectiveness of the factors on the N, P and $\mathrm{K}$ contents. It can also determine the effect for the main factors and the interactions effect between the factors (Golshani et al., 2013). The independent factors were taken into consideration during study the effect on the $\mathrm{N}$, $\mathrm{P}$ and $\mathrm{K}$ content. The $\mathrm{N}$ ranged from 0.14 to $8.68 \mathrm{mg} / \mathrm{L}$, while $\mathrm{P}$ content ranged from 0.33 to $1.86 \mathrm{mg} / \mathrm{L}$ and the $\mathrm{K}$ content ranged from 1.39 to $7.19 \mathrm{mg} / \mathrm{L}$. 
Table 3: $2^{5-1}$ Fractional Factor Design analysis using Design Expert software with its respective responses

\begin{tabular}{|c|c|c|c|c|c|c|c|c|}
\hline Run & $\begin{array}{c}\text { Factor } \\
1: \\
\text { Aging }\end{array}$ & $\begin{array}{c}\text { Factor } \\
2: \\
\text { MW size }\end{array}$ & $\begin{array}{c}\text { Factor } \\
3: \\
\mathrm{pH}\end{array}$ & $\begin{array}{l}\text { Factor } \\
\text { 4: } \\
\text { Drying }\end{array}$ & $\begin{array}{l}\text { Factor 5: } \\
\text { Composition }\end{array}$ & $\begin{array}{c}\text { Response } \\
1 \\
\mathrm{~N}(\mathrm{mg} / \mathrm{L}) \\
\end{array}$ & $\begin{array}{c}\text { Response } \\
2 \\
\mathrm{P}(\mathrm{mg} / \mathrm{L}) \\
\end{array}$ & $\begin{array}{c}\text { Response } 3 \\
\mathrm{~K}(\mathrm{mg} / \mathrm{L})\end{array}$ \\
\hline 1 & $\begin{array}{c}\text { Fresh } \\
0\end{array}$ & Cut & 7 & Sunlight & Mix MW \& SM & 1.85 & 0.73 & 2.31 \\
\hline 2 & 7 & Cut & 7 & Sunlight & MW & 4.02 & 1.46 & 2.97 \\
\hline 3 & $\begin{array}{c}\text { Fresh } \\
0\end{array}$ & Powder & 7 & Sunlight & MW & 6.02 & 1.55 & 3.41 \\
\hline 4 & 7 & Powder & 7 & Sunlight & Mix MW \& SM & 6.77 & 2.40 & 7.17 \\
\hline 5 & $\begin{array}{c}\text { Fresh } \\
0\end{array}$ & Cut & 8.5 & Sunlight & MW & 2.18 & 0.48 & 2.61 \\
\hline 6 & 7 & Cut & 8.5 & Sunlight & Mix MW \& SM & 2.85 & 1.40 & 3.98 \\
\hline 7 & $\begin{array}{c}\text { Fresh } \\
0\end{array}$ & Powder & 8.5 & Sunlight & Mix MW \& SM & 5.09 & 2.02 & 5.29 \\
\hline 8 & 7 & Powder & 8.5 & Sunlight & MW & 7.68 & 1.97 & 5.33 \\
\hline 9 & $\begin{array}{c}\text { Fresh } \\
0\end{array}$ & Cut & 7 & Oven $50^{\circ} \mathrm{C}$ & MW & 4.23 & 2.47 & 7.88 \\
\hline 10 & 7 & Cut & 7 & Oven $50^{\circ} \mathrm{C}$ & Mix MW \& SM & 2.03 & 2.02 & 2.07 \\
\hline 11 & $\begin{array}{c}\text { Fresh } \\
0\end{array}$ & Powder & 7 & Oven $50^{\circ} \mathrm{C}$ & Mix MW \& SM & 4.91 & 2.68 & 6.02 \\
\hline 12 & 7 & Powder & 7 & Oven $50^{\circ} \mathrm{C}$ & MW & 12.25 & 4.05 & 13.32 \\
\hline 13 & $\begin{array}{c}\text { Fresh } \\
0\end{array}$ & Cut & 8.5 & Oven $50{ }^{\circ} \mathrm{C}$ & Mix MW \& SM & 4.26 & 2.74 & 7.86 \\
\hline 14 & 7 & Cut & 8.5 & Oven $50^{\circ} \mathrm{C}$ & MW & 2.06 & 1.19 & 4.81 \\
\hline 15 & $\begin{array}{l}\text { Fresh } \\
0\end{array}$ & Powder & 8.5 & Oven $50^{\circ} \mathrm{C}$ & MW & 2.15 & 3.53 & 12.55 \\
\hline 16 & 7 & Powder & 8.5 & Oven $50^{\circ} \mathrm{C}$ & Mix MW \& SM & 6.30 & 3.20 & 6.09 \\
\hline
\end{tabular}

\section{Analysis of variance (ANOVA) for $N, P$ and $K$ contents}

The analysis of variance (ANOVA) was done to determine the significance of the model. Table 4 shows the ANOVA analysis summary of N, P and $\mathrm{K}$ contents to estimate the coefficient of the model, the significance of each parameter, and indicate the interaction strength of each parameter. The significance of a regression equation was checked using F-values while the $p$-values were used to check the significance of each coefficient (Wang et al., 2013). The p-value tests the data from the experiment with the identical means. If the $p$-value was less than 0.05 , the model terms are significant. Meanwhile, the $p$-value greater than 0.1 indicate the model terms are not significant.

For the ANOVA analysis, the F-value was 37.31 for N, 35.33 for $\mathrm{P}$ and 24.43 for K. For the $\mathrm{N}$ content, the significant model terms were B (MW size), A (aging), AB (aging and MW size) and $\mathrm{CE}$ ( $\mathrm{pH}$ and composition). For the $\mathrm{P}$ content, it was observed that the significant model terms were B (MW size), D (technique of drying), AD (aging and technique of drying) and $\mathrm{CE}$ ( $\mathrm{pH}$ and composition). For the $\mathrm{K}$ content, the $\mathrm{B}$ (MW size), $\mathrm{D}$ (technique of drying), $\mathrm{AC}$ (aging and $\mathrm{pH}$ ), $\mathrm{AD}$ (aging and technique of drying) and $\mathrm{DE}$ (technique of drying and composition) were significant model terms. 
The R-squared $\left(\mathrm{R}^{2}\right)$ from the ANOVA was used to indicate how close the data to the fitted regression line. Ölmez (2009) suggested that a good fit of a model $\mathrm{R}^{2}$ should more than $80 \%(0.80)$ for a good fitting model. The coefficient of determination $\left(\mathrm{R}^{2}\right)$ and adjusted coefficient of determination ( $\mathrm{R}^{2}$ adj) for the $\mathrm{N}, \mathrm{P}$ and $\mathrm{K}$ were 0.99 and $>0.94$, respectively. It specified that the model was a good fit and regression models explained the mechanism well since the $R^{2}$ for these response variables are higher than 0.80 . To express the $N, P$ and $\mathrm{K}$ contents as a function of independent variables, the final empirical model in terms of actual factors were determined as the regression Equations 1-3.

$$
\begin{aligned}
\mathrm{N} \text { content }= & 4.66+0.83 \mathrm{~A}+1.73 \mathrm{~B}-0.59 \mathrm{C}+0.11 \mathrm{D}-0.41 \mathrm{E}+1.03 \mathrm{AB} \\
& -0.60 \mathrm{AE}-0.50 \mathrm{BC}-0.49 \mathrm{CD}+0.96 \mathrm{CE} \\
\mathrm{P} \text { content }= & 2.12+0.093 \mathrm{~A}+0.56 \mathrm{~B}-0.051 \mathrm{C}+0.62 \mathrm{D}+0.030 \mathrm{E}+0.14 \mathrm{AB} \\
& -0.22 \mathrm{AC}-0.21 \mathrm{AD}-0.13 \mathrm{BE}+0.24 \mathrm{CE}-0.11 \mathrm{DE} \\
\mathrm{K} \text { content }= & 5.85-0.14 \mathrm{~A}+1.54 \mathrm{~B}+0.21 \mathrm{C}+1.72 \mathrm{D}-0.76 \mathrm{E}+0.72 \mathrm{AB} \\
& -0.88 \mathrm{AC}-0.86 \mathrm{AD}+0.38 \mathrm{BD}-0.50 \mathrm{BE}+0.50 \mathrm{CE}-1.31 \mathrm{DE}
\end{aligned}
$$

where $\mathrm{A}$ is aging, $\mathrm{B}$ is $\mathrm{MW}$ size, $\mathrm{C}$ is waste $\mathrm{pH}, \mathrm{D}$ is technique of drying and $\mathrm{E}$ is composition.

\section{Pareto Chart}

Main and interaction effects between factors based on Pareto chart for nitrogen $(\mathrm{N})$, phosphorus (P) and potassium (K) contents. The Pareto chart in Figure 1 demonstrates the main and interaction effects of the factors for the N. The MW size (B) gave the highest contribution for $\mathrm{N}$ content. It followed by aging (A), $\mathrm{pH}(\mathrm{C})$ and composition (E). There were five interaction effects that contributed on $\mathrm{N}$ content. There were two positive interaction effects between $\mathrm{AB}$ (aging and $\mathrm{MW}$ size) and between $\mathrm{CE}(\mathrm{pH}$ and composition). Positive effects referred to increase of $\mathrm{N}$ content as the value of factors increased. The interaction between AE (aging and composition), BC (MW size and $\mathrm{pH}$ ) and $\mathrm{CD}(\mathrm{pH}$ and technique of drying) represented negative effects. Negative effects referred to $\mathrm{N}$ content decreased as the value of the factors increased.

Figure 2 demonstrates the main effects and interaction effects of the factors for P. The technique of drying (D) has the highest contribution on P content and followed by MW size (B). For interaction effects, it shows to have three interaction effects that contributed on $\mathrm{P}$ content. There was one positive effects interaction between $\mathrm{CE}(\mathrm{pH}$ and composition). The interaction between $\mathrm{AC}$ (aging and $\mathrm{pH}$ ) and $\mathrm{AD}$ (aging and technique of drying) represented negative effects.

Figure 3 demonstrates the main effects and interaction effects of the factors for K. The technique of drying (D) gave the highest contribution on K content followed by MW size (B) and composition (E). It has four interaction effects that contributed to the K content. There was one positive effect interaction between $\mathrm{AB}$ (aging and MW size). The interaction between $\mathrm{AC}$ (aging and $\mathrm{pH}$ ), $\mathrm{AD}$ (aging and technique of drying) and $\mathrm{DE}$ (technique of drying and composition) represented negative effects. 
Table 4: ANOVA analysis for N, P and $\mathrm{K}$

\begin{tabular}{|c|c|c|c|c|c|c|c|}
\hline \multicolumn{4}{|c|}{$\mathrm{N}$} & \multicolumn{4}{|c|}{$\mathrm{P}$} \\
\hline Source & $\begin{array}{l}\text { Sum of } \\
\text { Squares }\end{array}$ & F-value & $\begin{array}{c}\text { p-value } \\
\text { Prob }> \\
\text { F }\end{array}$ & Source & $\begin{array}{l}\text { Sum of } \\
\text { Squares }\end{array}$ & F-value & $\begin{array}{c}\text { p-value } \\
\text { Prob }> \\
\text { F }\end{array}$ \\
\hline Model & $1.13 \mathrm{E}+08$ & 37.31 & 0.0005 & Model & $1.40 \mathrm{E}+07$ & 35.33 & 0.0018 \\
\hline A: Aging & $1.10 \mathrm{E}+07$ & 36.57 & 0.0018 & A: Aging & 137289 & 3.70 & 0.1269 \\
\hline B: MW size & $4.80 \mathrm{E}+07$ & 158.70 & $\begin{array}{c}< \\
0.0001\end{array}$ & B: MW size & 4974796 & 133.95 & 0.0003 \\
\hline $\mathrm{C}: \mathrm{pH}$ & 5652506 & 18.73 & 0.0075 & $\mathrm{C}: \mathrm{pH}$ & 42199.4 & 1.14 & 0.3465 \\
\hline $\begin{array}{l}\text { D: Technique } \\
\text { of Drying }\end{array}$ & 189443 & 0.63 & 0.4641 & $\begin{array}{l}\text { D: Technique } \\
\text { of Drying }\end{array}$ & 6073637 & 163.54 & 0.0002 \\
\hline $\begin{array}{l}\text { E: } \\
\text { Composition }\end{array}$ & 2666689 & 8.84 & 0.0311 & $\begin{array}{l}\text { E: } \\
\text { Composition }\end{array}$ & 14768.3 & 0.40 & 0.5625 \\
\hline $\mathrm{AB}$ & $1.70 \mathrm{E}+07$ & 55.71 & 0.0007 & $\mathrm{AB}$ & 299674 & 8.07 & 0.0468 \\
\hline $\mathrm{AE}$ & 5750404 & 19.06 & 0.0073 & $\mathrm{AC}$ & 772509 & 20.80 & 0.0103 \\
\hline $\mathrm{BC}$ & 3939233 & 13.05 & 0.0153 & $\mathrm{AD}$ & 733635 & 19.75 & 0.0113 \\
\hline $\mathrm{CD}$ & 3801525 & 12,60 & 0.0164 & $\mathrm{BE}$ & 270998 & 7.30 & 0.054 \\
\hline $\mathrm{CE}$ & $1.50 \mathrm{E}+07$ & 49.18 & 0.0009 & $\mathrm{CE}$ & 936201 & 25.21 & 0.0074 \\
\hline Residual & 1508853 & & & $\mathrm{DE}$ & 176421 & 4.75 & 0.0948 \\
\hline Cor Total & $1.14 \mathrm{E}+08$ & & & Residual & 148552 & & \\
\hline R-Squared & 0.99 & & & Cor Total & $1.50 \mathrm{E}+07$ & & \\
\hline $\begin{array}{l}\text { Adj R- } \\
\text { Squared }\end{array}$ & 0.96 & & & R-Squared & 0.99 & & \\
\hline & & & & Adj R-Squared & 0.96 & & \\
\hline
\end{tabular}

\begin{tabular}{lccc}
\hline & $\mathrm{P}$ & & \\
\hline Source & $\begin{array}{c}\text { Sum of } \\
\text { Squares }\end{array}$ & F-value & $\begin{array}{c}\text { p-value } \\
\text { Prob }> \\
\text { F }\end{array}$ \\
\hline Model & $1.66 \mathrm{E}+08$ & 24.43 & 0.0116 \\
A: Aging & 300907 & 0.53 & 0.5184 \\
B: MW size & $3.80 \mathrm{E}+07$ & 67.45 & 0.0038 \\
C: pH & 714194 & 1.26 & 0.3427 \\
D: Technique & $4.70 \mathrm{E}+07$ & 83.72 & 0.0028 \\
of Drying & & & \\
E: & 9139738 & 16.17 & 0.0276 \\
Composition & 8214243 & 14.54 & 0.0317 \\
AB & $1.20 \mathrm{E}+07$ & 21.70 & 0.0187 \\
AC & $1.20 \mathrm{E}+07$ & 21.17 & 0.0193 \\
AD & 2276930 & 4.01 & 0.1383 \\
BD & 3984415 & 7.05 & 0.0766 \\
BE & 3926739 & 6.95 & 0.0779 \\
CE & $2.70 \mathrm{E}+07$ & 48.59 & 0.0061 \\
DE & 1695175 & & \\
Residual & $1.67 \mathrm{E}+08$ & & \\
Cor Total & 0.99 & & \\
R-Squared & 0.95 & & \\
Adj R- & & & \\
Squared & &
\end{tabular}




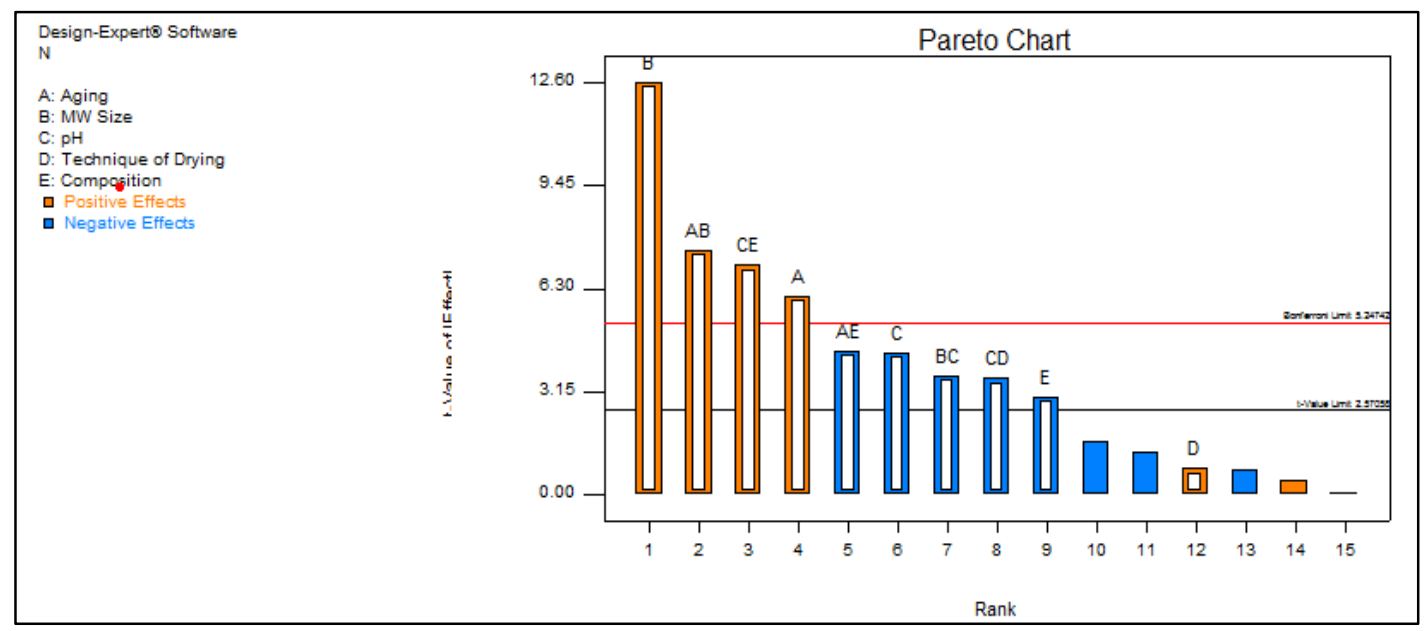

Figure 1: Pareto chart for nitrogen $(\mathrm{N})$ main and interaction effect between factors

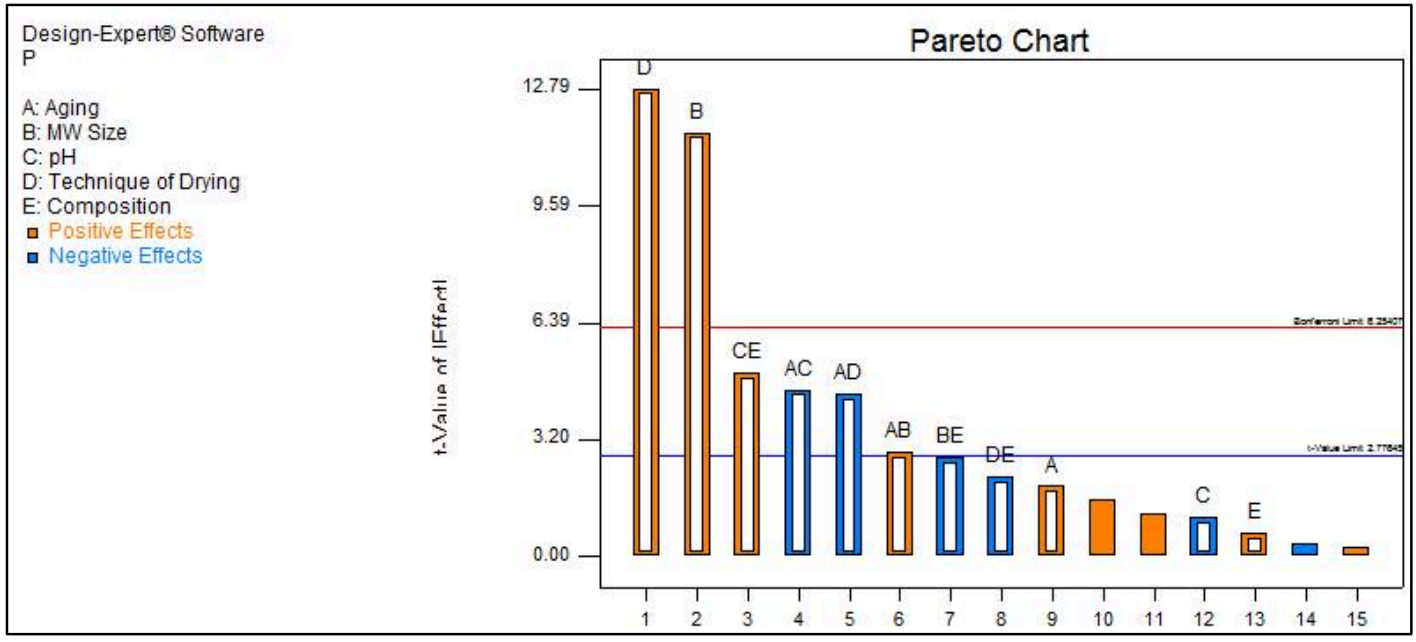

Figure 2: Pareto chart for phosphorus $(\mathrm{P})$ main and interaction effect between factors

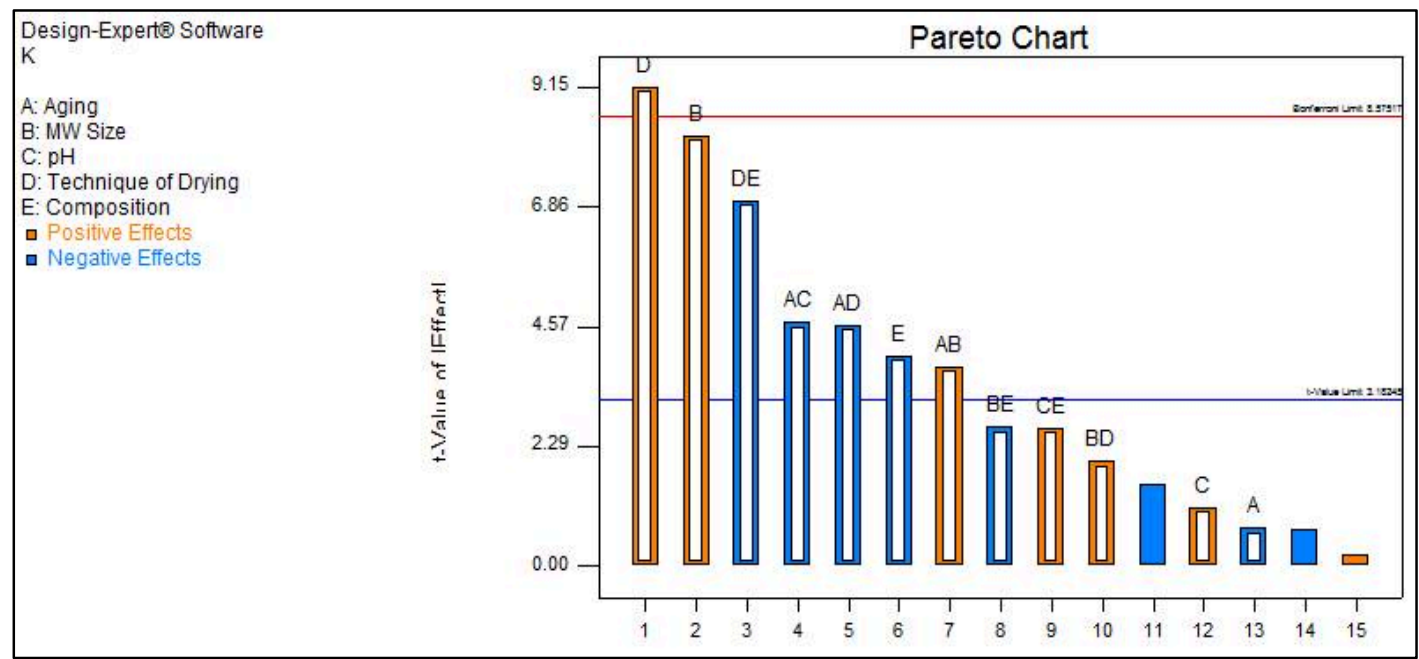

Figure 3: Pareto chart for potassium $(\mathrm{K})$ main and interaction effect between factors 


\section{Effect of independent processing factors on $\mathbf{N}$ content}

The effect of two independent factors on the $\mathrm{N}$ content is shown in Figure 4. The $\mathrm{N}$ content increases with the increasing of aging days as shown in Figure 4a. The $\mathrm{N}$ content was lower at 0 -day aging than at 7 -day aging. $\mathrm{N}$ content achieved $2.83 \mathrm{mg} / \mathrm{L}$ at 0 -day aging and $3.64 \mathrm{mg} / \mathrm{L}$ at 7-day aging. Thus, it has significant difference with $22.27 \%$ increment of $\mathrm{N}$ between 0 -day aging and 7-day aging. The difference was due to increase of freely available $\mathrm{N}$ after aging (Hubbe et al., 2010). While, Figure $4 \mathrm{~b}$ demonstrates, the $\mathrm{N}$ content increases with the decreasing of MW size. The $\mathrm{N}$ content achieved was 4.24 $\mathrm{mg} / \mathrm{L}$ for powder size factor, while for cut size factor, only $2.83 \mathrm{mg} / \mathrm{L}$ was achieved. It indicates that higher $\mathrm{N}$ content achieved using the powder size form. It also showed that there was a significant difference of $\mathrm{N}$ content in both MW size. As the MW size decreases, the availability $\mathrm{N}$ increases as it dissolves more in water. Thus, it increases $\mathrm{N}$ content in MW. Sangamithirai et al. (2015) stated that the smallest particles have much more surface area for a given volume and more rapidly broken down by microbes. Several authors such as $\mathrm{Xu}$ et al. (2014) and Jing et al. (2007) concentrated on size as important factor controlling mobility of nutrients in soil by changing nutrients speciation. Therefore, MW size gave the highest contribution in $\mathrm{N}$ content.

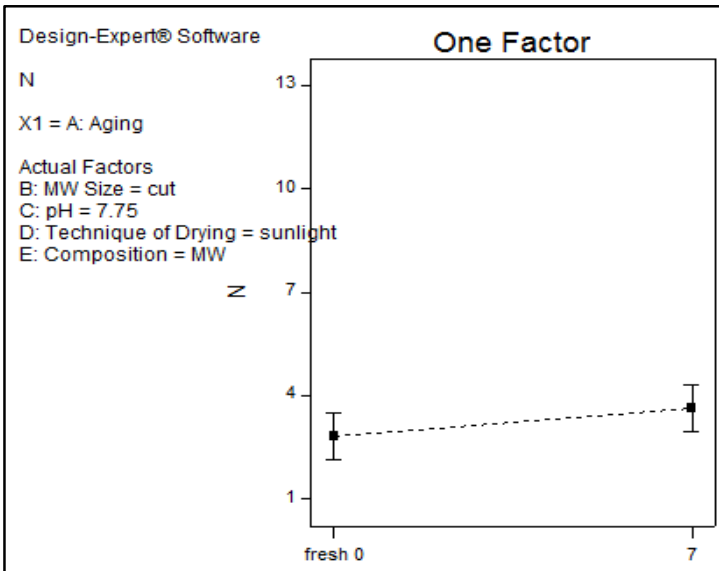

(a) Aging factor

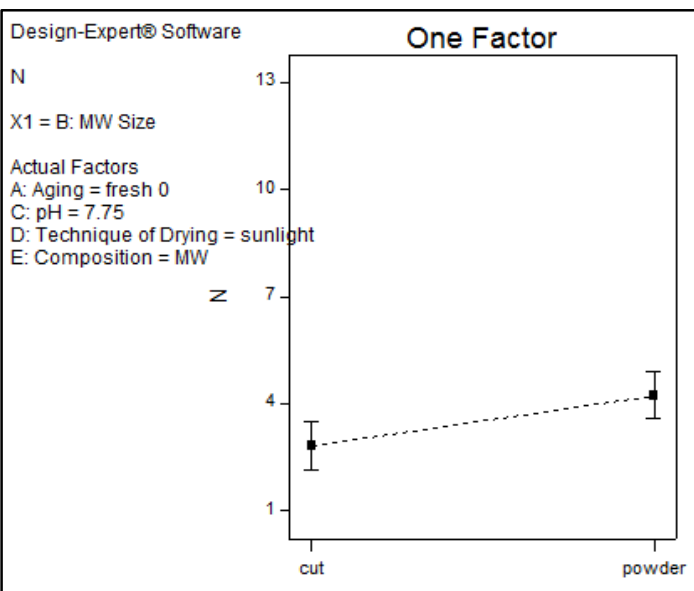

(b) MW size

Figure 4: Most effective independent factors in N content. (a) Aging factor; (b) MW size

\section{Interaction effects between factors on $\mathbf{N}$ content}

Figure 5a demonstrates the interaction between A and B (aging and MW size). It gave the highest positive contribution effect on $\mathrm{N}$ content based on the Pareto chart (Figure 1). Higher N content achieved as MW aging 7-day and MW in powder form size. At the 0day aging $\mathrm{N}$ content higher in powder form than cut size. Dardanelli et al., (2010) found that the use of long composting and small particle size increase the $\mathrm{N}$ content and avoid loss as $\mathrm{NH}_{3}$ gas during composting. Saleh et al., (2013) reported there $\mathrm{N}$ increases as dry matter losses increases when composting. For the interaction between $\mathrm{C}$ and $\mathrm{E}(\mathrm{pH}$ and composition) in Figure 5b, it shows two behaviors. First, the higher $\mathrm{N}$ content was achieved in MW only at $\mathrm{pH}$ 7. Second, higher $\mathrm{N}$ content achieved in composition of mix $\mathrm{MW}$ and $\mathrm{SM}$ at $\mathrm{pH} 8.5$. However, the highest $\mathrm{N}$ content at $\mathrm{pH} 7(3.40 \mathrm{mg} / \mathrm{L})$ was almost similar with pH 8.5 (4.40 mg/L). According to Wang et al., (2013) and Charisiou (2014), 
the $\mathrm{N}$ content decreases when composting sewage sludge enriched with lime $(\mathrm{pH}<7)$. Thus, the $\mathrm{pH}$ need to keep in the neutral range (7-8.5) as mention by Chandrasekar (2005).

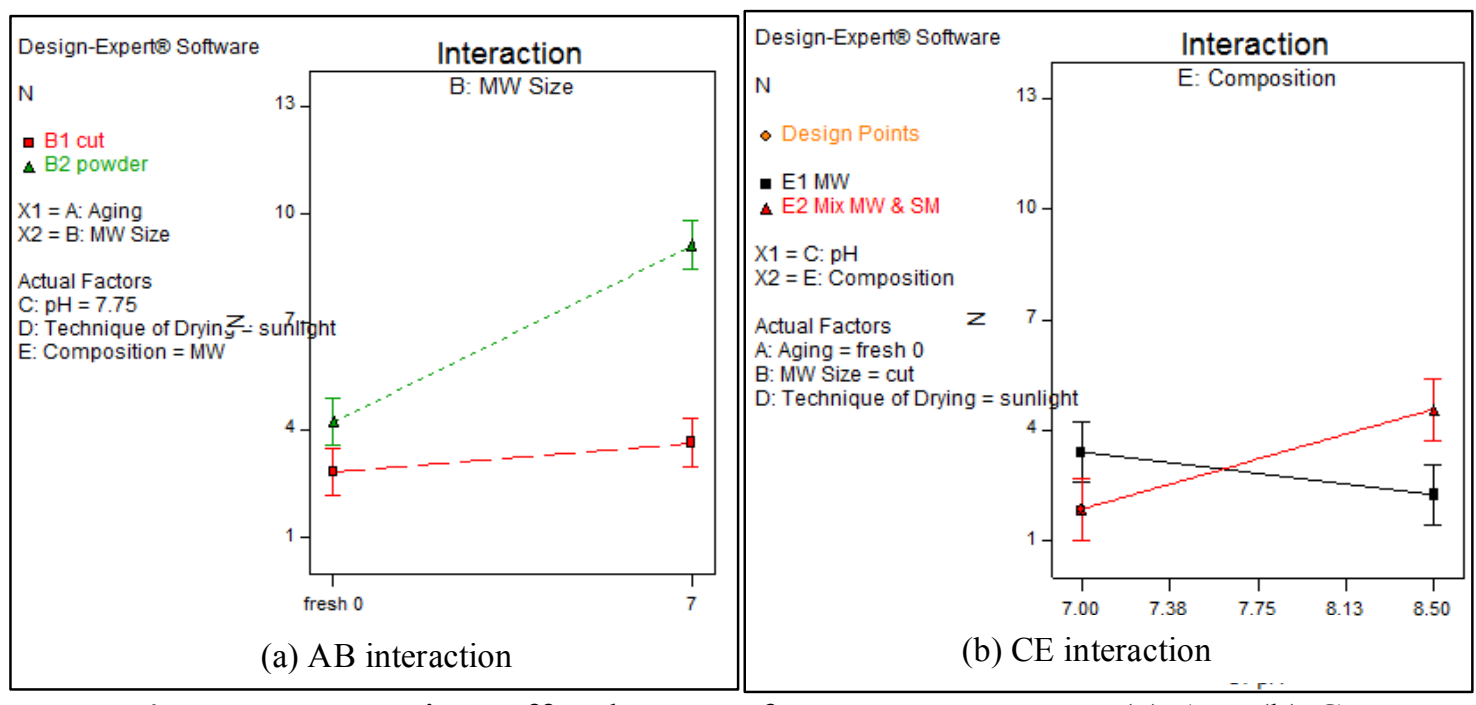

Figure 5: Interactions effect between factors on $\mathrm{N}$ content; (a) AB; (b) $\mathrm{CE}$

\section{Effect of independent processing factors on $P$ content}

There were two independent variables affected the $\mathrm{P}$ content as shown in Figure 6. In Figure 6a, MW size affects the P content in MW. The P content achieved was about $1.61 \mathrm{mg} / \mathrm{L}$ at powder size compare to cut size which is $0.51 \mathrm{mg} / \mathrm{L}$ only. It shows there were significant differences at both MW size. Kaye et al., (2003) state size of organic waste highly influence the nutrients mineralization. P content present higher in powder size compare in cut size. Big size of samples has a smaller total surface area and less accessible to microbes than the small size samples (Duong et al., 2013). Duong et al. (2013) stated that the powder composts release more P than granular compost. As the MW size smaller, the availability $\mathrm{P}$ increases as it dissolves more in water. Figure $6 \mathrm{~b}$ shows that $\mathrm{P}$ content in MW affected by the technique of drying. P content was $0.51 \mathrm{mg} / \mathrm{L}$ at sunlight drying and $2.38 \mathrm{mg} / \mathrm{L}$ at oven drying. It also showed that there were significant differences at both technique of drying. This may be due to the rapid increase in microorganism activities and interaction that occurred. The P content in MW was lower at sunlight drying compare to oven drying. The trend of the results in this study generally indicates that oven drying retains higher P content in MW than sun-drying. 


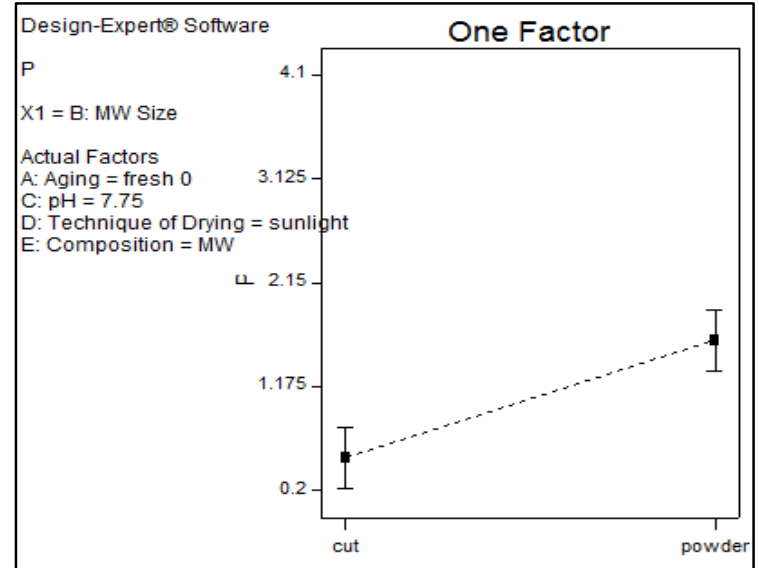

(a) MW size

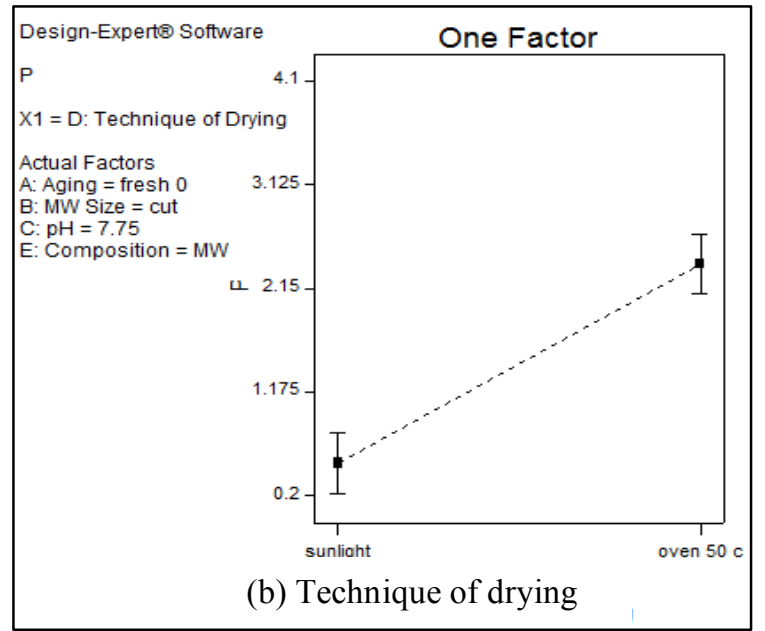

(b) Technique of drying

Figure 6: Most effective independent factors in P content; (a) MW size;

(b) Technique of drying

\section{Interaction effects between factors on $P$ content}

Figure $7 \mathrm{a}$ shows the interaction between $\mathrm{C}$ and $\mathrm{E}$ (composition and $\mathrm{pH}$ ) has high significant effect to the $\mathrm{P}$ content. It gave the highest positive contribution effect on $\mathrm{P}$ content based on Pareto chart (Figure 2). It can be observed that at $\mathrm{pH} \mathrm{7,} \mathrm{the} \mathrm{P}$ content almost similar either in the presence of MW only or Mix MW and SM. But at $\mathrm{pH} 8.5$ with the addition of spent medium (SM), the $\mathrm{P}$ content was high. The $\mathrm{pH}$ influences the rate of mineralization which affects the $\mathrm{P}$ content. The addition of inorganic substance at high $\mathrm{pH}$ increases the rate of mineralization due to the different micro-organisms activity (Lou et al., 2015). Besides, the SM contains mix culture tends to increase the P content (Kwak et al., 2015). The interaction between A and D (aging and technique of drying) is shown in Figure $7 \mathrm{~b}$. At 0 -day of aging, the $\mathrm{P}$ content higher under oven drying than sunlight drying. However at 7-day aging, the P content decreases under oven drying because it has been leached away (Ige et al., 2007).

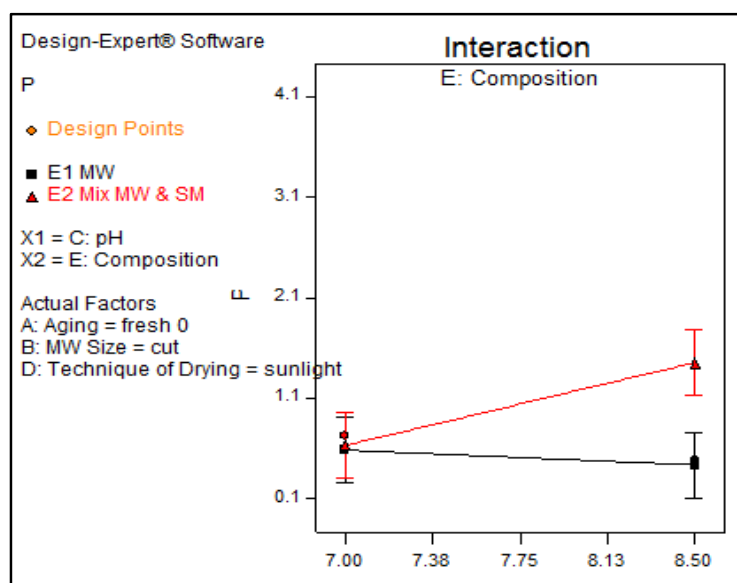

(a) CE interaction

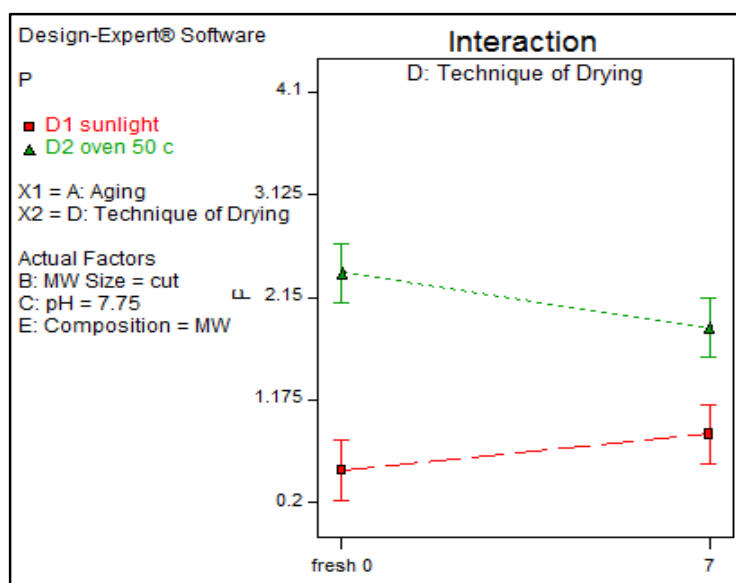

(b) $\mathrm{AD}$ interaction

Figure 7: Most effective Interaction effect between factors on P; (a) CE; (b) AD 


\section{Effect of independent processing factors on $K$ content}

The effects of two independent variables on the K content in MW are shown in Figure 8. In Figure 8a, MW size affects the K content. For powder size factor, K content was $3.08 \mathrm{mg} / \mathrm{L}$. However, it was only $1.90 \mathrm{mg} / \mathrm{L}$ for cut size factor. It shows that higher $\mathrm{K}$ content was achieved by using powder size. It also shows that there was significant difference of $\mathrm{K}$ at both MW sizes. K content is higher in powder size compare in cut size. Small size have a larger total surface area and more accessible to microbes than the big size (Tahir et al., 2016). Figure $8 \mathrm{~b}$ shows the effects of technique of drying to K content. The K content observed was $1.90 \mathrm{mg} / \mathrm{L}$ at sunlight drying while $8.94 \mathrm{mg} / \mathrm{L}$ at oven drying. It shows that there was significant difference on $\mathrm{K}$ content.

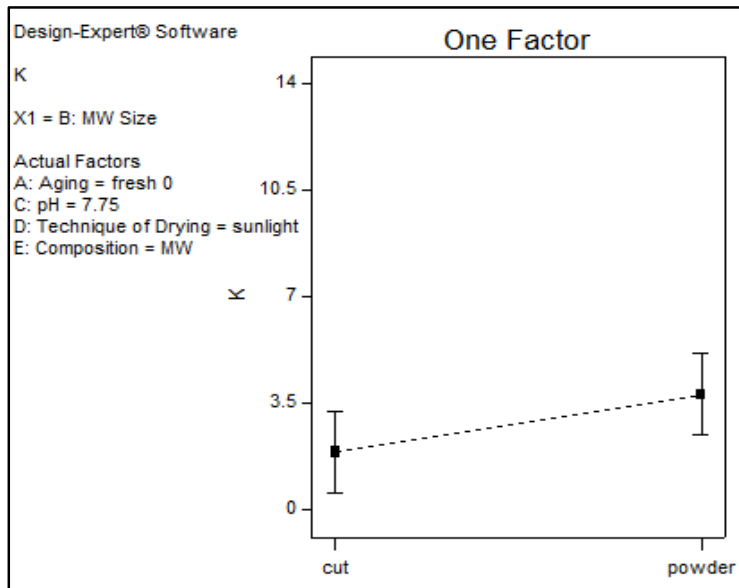

(a) MW size

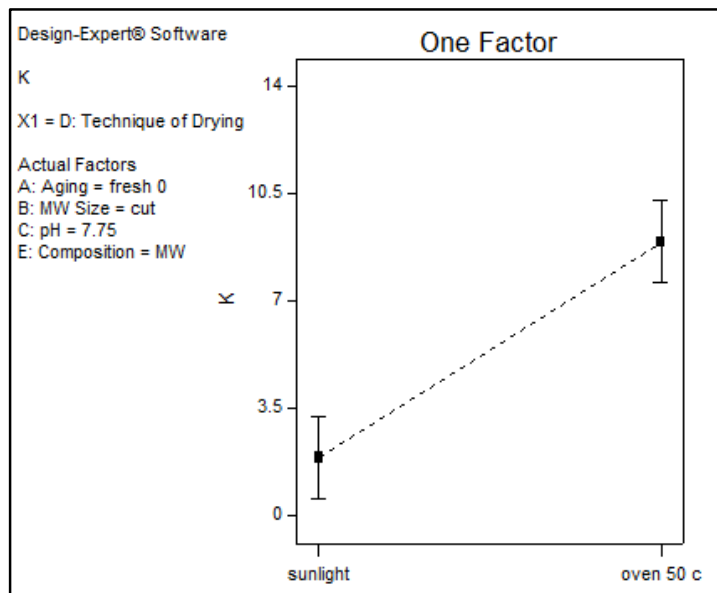

(b) Technique of drying

Figure 8: Most effective independent factors in K content; (a) MW size;

(b) Technique of drying

\section{Interaction effects between factors on $K$ content}

Interaction between $\mathrm{D}$ and $\mathrm{E}$ (technique of drying and composition) have the highest significant to the K content in MW based on Pareto chart (Figure 3). At the sunlight drying, the K content was higher in the present of SM $(4.00 \mathrm{mg} / \mathrm{L})$ compared to MW only $(1.90 \mathrm{mg} / \mathrm{L})$ (Figure 9a). While at oven drying, the K content was higher in MW only $(8.90 \mathrm{mg} / \mathrm{L})$ compare to Mix MW and SM (5.80 mg/L). Banlangsawan et al. (2016) observed that the addition of organic matter and constant drying technique increase the nutrients content. Figure $9 \mathrm{~b}$ shows the interaction between $\mathrm{A}$ and $\mathrm{C}$ (aging and $\mathrm{pH}$ ). At 0 -day aging, the $\mathrm{K}$ content was higher at $\mathrm{pH} 8.5(2.50 \mathrm{mg} / \mathrm{L})$ compared to $\mathrm{pH} 7(1.30$ $\mathrm{mg} / \mathrm{L})$. While at 7-day aging, the $\mathrm{K}$ content was higher at $\mathrm{pH} 7(3.10 \mathrm{mg} / \mathrm{L})$ compared to $\mathrm{pH} 8.5(0.77 \mathrm{mg} / \mathrm{L})$. At 0 -day aging, there was no significant difference between the $\mathrm{K}$ content at both $\mathrm{pH}$ level. But at 7-day aging, there was a significant difference between the $\mathrm{K}$ content. Furthermore, the K content in the MW dried for long period increased more than twice compared to the fresh MW. The K in MW mostly preferable at $\mathrm{pH} 7$ since it provides better degradation of organic matter and increases nutrients. Sundberg et al. (2013) agreed that the rate of organic waste decomposition was high at $\mathrm{pH} 7$. Figure 9c shows the interaction effect between $\mathrm{A}$ and $\mathrm{D}$ (aging and technique of drying). The $\mathrm{K}$ content decreases as it was dried for 7 days under oven drying. While for sunlight drying, the $\mathrm{K}$ content remains similar even it was dried for 7 days. During the drying, the $\mathrm{K}$ 
content dissolves in water and leached away. Kargar et al. (2015) also stated that K would be dissolved and leached by water as it was leachable nutrient.
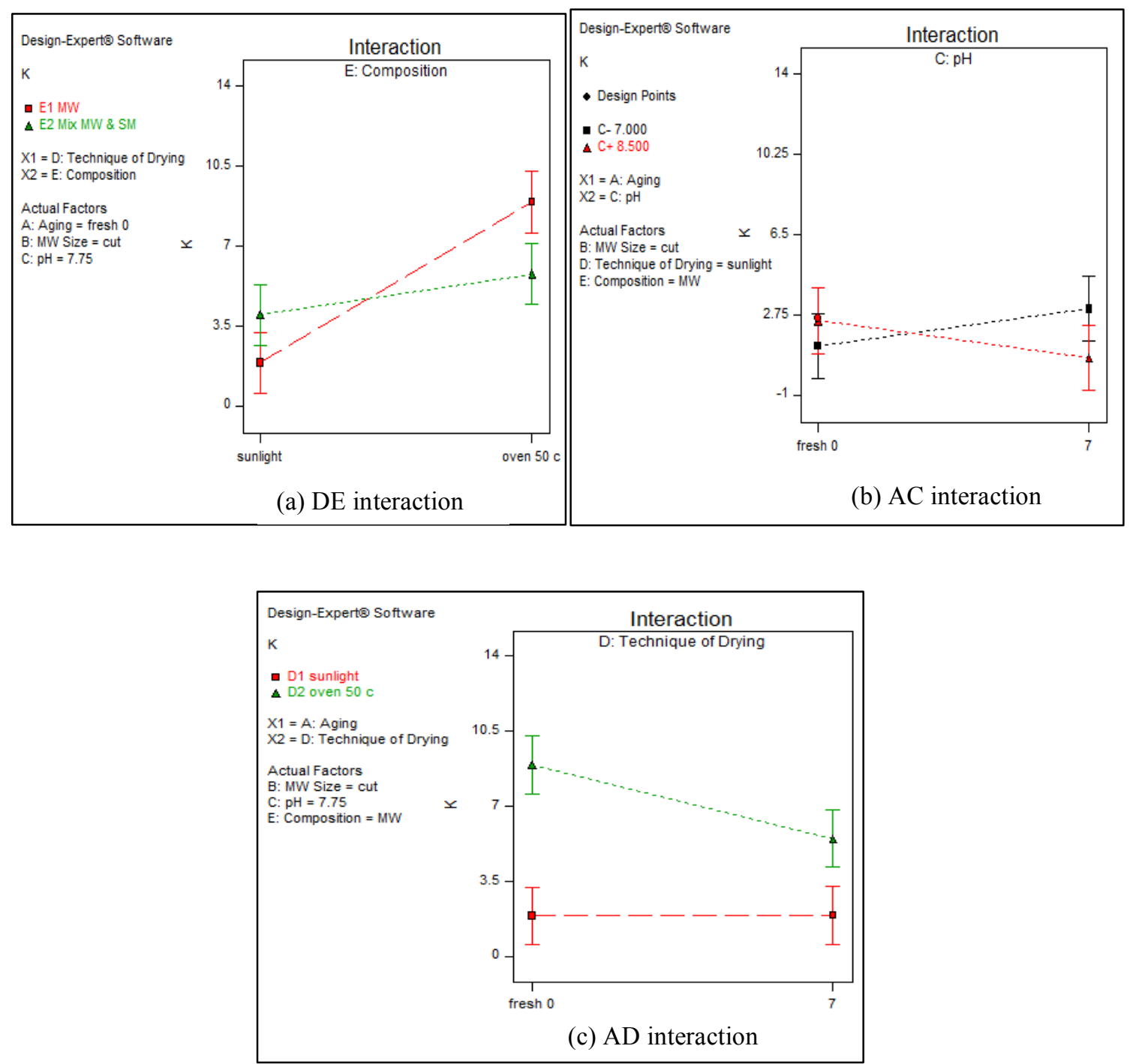

Figure 9: Interaction effect between factors on $\mathrm{K}$; (a) CE; (b) AC; (c) AD

\section{Validation experiment}

Equations 1-3 predict the $\mathrm{N}, \mathrm{P}$ and $\mathrm{K}$ contents by using the best processing conditions. The criteria setup to select the best processing conditions is given in Table 5.

Table 5: Criteria for the best processing conditions

\begin{tabular}{lcc}
\hline \multicolumn{1}{c}{ Criteria } & Goal & Value \\
\hline Aging & In range & 0 day-7 days \\
MW Size & In range & Cut or powder \\
$\mathrm{pH}$ & In range & $7-8.5$ \\
Technique of Drying & In range & sunlight or oven $50{ }^{\circ} \mathrm{C}$ \\
Composition & In range & MW only or Mix MW \& SM \\
$\mathrm{N}$ & Maximize & - \\
$\mathrm{P}$ & Maximize & - \\
$\mathrm{K}$ & Maximize & - \\
\hline
\end{tabular}


The suggested best processing conditions by Design Expert V.7 and their predicted N, P and $\mathrm{K}$ contents are shown in Table 6 . The experiments were carried out to verify this suggested best condition and the results of the experiments are shown in Table 7 . The error from this experiment was calculated by Equation 4. Run 3 was chosen as the best processing condition. This was due to their error of $8.69 \%$ for $\mathrm{N}, 1 \%$ for $\mathrm{P}$ and $3.06 \%$ for $\mathrm{K}$ which were acceptable values since the error does not exceed $10 \%$.

$$
\text { Error }=100 \% \times\left|\frac{\text { actual-predicted }}{\text { actual }}\right|
$$

Table 6: Best condition for $\mathrm{N}, \mathrm{P}$ and $\mathrm{K}$ contents

\begin{tabular}{ccccccccc}
\hline Run & $\begin{array}{c}\text { Factor } \\
\text { 1: } \\
\text { Aging }\end{array}$ & $\begin{array}{c}\text { Factor } \\
\text { 2: MW } \\
\text { Size }\end{array}$ & $\begin{array}{c}\text { Factor } \\
\text { 3: } \mathrm{pH}\end{array}$ & $\begin{array}{c}\text { Factor 4: } \\
\text { Technique } \\
\text { of drying }\end{array}$ & $\begin{array}{c}\text { Factor 5: } \\
\text { Compositio } \\
\mathrm{n}\end{array}$ & $\begin{array}{c}\text { Predicte } \\
\mathrm{d} \mathrm{N} \\
(\mathrm{mg} / \mathrm{L})\end{array}$ & $\begin{array}{c}\text { Predicted } \\
\mathrm{P}(\mathrm{mg} / \mathrm{L})\end{array}$ & $\begin{array}{c}\text { Predicted } \\
\mathrm{K}(\mathrm{mg} / \mathrm{L})\end{array}$ \\
\hline 1 & 7 & Powder & 7 & Oven $50{ }^{\circ} \mathrm{C}$ & $\mathrm{MW}$ & 11.91 & 4.02 & 12.93 \\
2 & Fresh 0 & Powder & 7 & Oven 50 ${ }^{\circ} \mathrm{C}$ & $\mathrm{MW}$ & 7.00 & 3.55 & 11.75 \\
3 & 7 & Powder & 7 & Sunlight & MW & 13.23 & 3.01 & 7.85 \\
\hline
\end{tabular}

Table 7: Data from validation experiment

\begin{tabular}{cccccccccc}
\hline Run & $\begin{array}{c}\text { Exp.N } \\
(\mathrm{mg} / \mathrm{L})\end{array}$ & $\begin{array}{c}\text { Predicted } \\
\mathrm{N}\end{array}$ & $\begin{array}{c}\text { Error } \\
(\mathrm{mg} / \mathrm{L})\end{array}$ & $\begin{array}{c}\text { Exp. P } \\
(\mathrm{mg} / \mathrm{L})\end{array}$ & $\begin{array}{c}\text { Predicted } \\
\mathrm{P}(\mathrm{mg} / \mathrm{L})\end{array}$ & $\begin{array}{c}\text { Error } \\
\%\end{array}$ & $\begin{array}{c}\text { Exp.K } \\
(\mathrm{mg} / \mathrm{L})\end{array}$ & $\begin{array}{c}\text { Predicted } \\
\mathrm{K}\end{array}$ & $\begin{array}{c}\text { Error } \\
\%\end{array}$ \\
1 & 10.53 & 11.91 & 11.59 & 3.24 & 4.02 & 19.40 & 14.58 & 12.93 & 12.76 \\
2 & 5.32 & 7.00 & 24.00 & 4.16 & 3.55 & 17.18 & 12.01 & 11.75 & 2.21 \\
$\mathbf{3}$ & $\mathbf{1 2 . 0 8}$ & $\mathbf{1 3 . 2 3}$ & $\mathbf{8 . 6 9}$ & $\mathbf{3 . 0 4}$ & $\mathbf{3 . 0 1}$ & $\mathbf{0 . 9 9}$ & $\mathbf{8 . 0 9}$ & $\mathbf{7 . 8 5}$ & $\mathbf{3 . 0 6}$ \\
\hline
\end{tabular}

\subsection{CONCLUSION}

It can be concluded that the MW contains high $\mathrm{N}, \mathrm{P}$ and $\mathrm{K}$ contents. To obtain the maximum amount of $\mathrm{N}, \mathrm{P}$ and $\mathrm{K}$ contents, the effects of various processing factors were analyzed using Design Expert software V7. The results showed that the most significant factors in $\mathrm{N}$ content were MW size and aging of waste. Meanwhile for $\mathrm{P}$ and $\mathrm{K}$ contents, technique of drying and MW size were the most significant factors. The best condition for the processing factors of MW was identified to achieve a maximum amount of $\mathrm{N}, \mathrm{P}$ and $\mathrm{K}$ contents, which were aging of 7 days, MW size in powder form, waste $\mathrm{pH}$ at 7 , sun light drying and the composition of MW only. The predicted results were compared with the experimental results with the error does not exceed $10 \%$ for $\mathrm{N}, \mathrm{P}$ and $\mathrm{K}$. Based on the best conditions proposed, the $\mathrm{N}(12.08 \mathrm{mg} / \mathrm{L}), \mathrm{P}(3.04 \mathrm{mg} / \mathrm{L})$ and $\mathrm{K}(8.09 \mathrm{mg} / \mathrm{L})$ contents were achieved.

\section{REFERENCES}

Ahmad, R., Arshad, M., Khalid, A., \& Zahir, Z. A. (2008). Effectiveness of organic-/biofertilizer supplemented with chemical fertilizers for improving soil water retention, aggregate stability, growth and nutrient uptake of maize (Zea mays L.). Journal of Sustainable Agriculture, 31(4), 57-77. 
Banlangsawan, N., Sripanidkulchai, B., \& Sanoamuang, N. (2016). Investigation of antioxidative, antityrosinase and cytotoxic effects of extract of irradiated oyster mushroom. Songklanakarin Journal of Science \& Technology, 38(1).

Çağlarırmak, N. (2007). The nutrients of exotic mushrooms (Lentinula edodes and Pleurotus species) and an estimated approach to the volatile compounds. Food chemistry, 105(3), 1188-1194.

Chandrasekar, B. R., Ambrose, G., \& Jayabalan, N. (2005). Influence of biofertilizers and nitrogen source level on the growth and yield of Echinochloa frumentacea (Roxb) Link. Journal of Agricultural Technology, 1(2), 223-234.

Charisiou, N. D., Goula, M. A., \& Papadakis, V. G. (2014,). Composting Process of Olive Tree Prunings: Assessment of Nitrogen and Carbon Losses. In ATHENS2014 (2nd International Conference on Sustainable Solid Waste Management), Athens, Greece.

Chatterjee, S., Saikia, A., Dutta, P., Ghosh, D., Pangging, G., \& Goswami, A. K. (2006). Biodiversity significance of North East India. WWF-India, New Delhi, 1-71.

Dardanelli, M. S., Carletti, S. M., Paulucci, N. S., Medeot, D. B., Cáceres, E. R., Vita, F. A., ... \& Garcia, M. B. (2010). Benefits of plant growth-promoting rhizobacteria and rhizobia in agriculture. In Plant growth and health promoting bacteria (pp. 1-20). Springer Berlin Heidelberg.

Duong, T. T., Verma, S. L., Penfold, C., \& Marschner, P. (2013). Nutrient release from composts into the surrounding soil. Geoderma, 195, 42-47.

Fawzy, Z. F., El-Nemr, M. A., \& Saleh, S. A. (2007). Influence of levels and methods of potassium fertilizer application on growth and yield of eggplant. Journal of Applied Sciences Research, 3(1), 42-49.

Fuentes, B., de la Luz Mora, M., Bolan, N. S., \& Naidu, R. (2008). Assessment of phosphorus bioavailability from organic wastes in soil. Developments in Soil Science, 32, 363-411.

Golshani, T., Jorjani, E., Chelgani, S. C., Shafaei, S. Z., \& Nafechi, Y. H. (2013). Modeling and process optimization for microbial desulfurization of coal by using a two-level full factorial design. International Journal of Mining Science and Technology, 23(2), 261-265.

Hubbe, M. A., Nazhad, M., \& Sánchez, C. (2010). Composting as a way to convert cellulosic biomass and organic waste into high-value soil amendments: A review. BioResources, 5(4), 2808-2854.

Ige, D. V., Akinremi, O. O., \& Flaten, D. N. (2007). Direct and indirect effects of soil properties on phosphorus retention capacity. Soil Science Society of America Journal, 71(1), 95-100.

Jing, Y. D., He, Z. L., \& Yang, X. E. (2007). Effects of pH, organic acids, and competitive cations on mercury desorption in soils. Chemosphere, 69(10), 1662-1669.

Karami, A., Sepehri, A., Hamzei, J., \& Salimi, G. (2011). Effect of nitrogen and phosphorous biofertilizers on quantitative and qualitative traits of Borage (Borago officinalis L.) under water deficit stress. Plant Products Technology, 11(1), 3750.

Kargar, M., Jutras, P., Clark, O. G., Hendershot, W. H., \& Prasher, S. O. (2015). Macronutrient availability in surface soil of urban tree pits influenced by land use, soil age, and soil organic matter content. Urban ecosystems, 18(3), 921-936.

Kaye, J. P., Binkley, D., \& Rhoades, C. (2003). Stable soil nitrogen accumulation and flexible organic matter stoichiometry during primary floodplain succession. Biogeochemistry, 63(1), 1-22. 
Kwak, W., Ren, C., \& Lu, H. (2007). Selection of Blocked Two-Level Fractional Factorial Designs for Agricultural Experiments. Annual Conference on Applied Statistics in Agriculture, 62-73.

Keding, G., Weinberger, K., Swai, I., \& Mndiga, H. (2007). Diversity, traits and use of traditional vegetables in Tanzania. AVRDC-WorldVegetableCenter.

Lou, Z., Zhu, J., Wang, Z., Baig, S. A., Fang, L., Hu, B., \& Xu, X. (2015). Release characteristics and control of nitrogen, phosphate, organic matter from spent mushroom compost amended soil in a column experiment. Process Safety and Environmental Protection, 98, 417-423.

Mahdi, S. S., Hassan, G. I., Samoon, S. A., Rather, H. A., Dar, S. A., \& Zehra, B. (2010). Bio-fertilizers in organic agriculture. Journal of Phytology, 2(10).

Ölmez, T. (2009). The optimization of $\mathrm{Cr}$ (VI) reduction and removal by electrocoagulation using response surface methodology. Journal of Hazardous Materials, 162(2), 1371-1378.

Peyvast, G. H., Olfati, J. A., Madeni, S., \& Forghani, A. (2008b). Effect of vermicompost on the growth and yield of spinach (Spinacia oleracea L.). Journal of Food Agriculture and Environment, 6(1), 110.

Peyvast, G., Moghaddam, M. S., \& Olfati, J. A. (2007a). Effect of municipal solid waste compost on weed control, yield and some quality indices of green pepper (Capsicum annuum L.). Biosci. Biotechnol. Res. Asia, 4(2), 449-456.

Saleh, A. S., Zhang, Q., Chen, J., \& Shen, Q. (2013). Millet grains: nutritional quality, processing, and potential health benefits. Comprehensive Reviews in Food Science and Food Safety, 12(3), 281-295.

Sangamithirai, K. M., Jayapriya, J., Hema, J., \& Manoj, R. (2015). Evaluation of in-vessel co-composting of yard waste and development of kinetic models for cocomposting. International Journal of Recycling of Organic Waste in Agriculture, 4(3), 157-165.

Shabani, G., Ardakani, M. R., Chaichi, M. R., Friedel, J., Khavazi, K., \& Eshghizadeh, H. R. (2011). Effect of different fertilizing systems on seed yield and phosphorus uptake in annual medics under dryland farming conditions. Notulae Botanicae Horti Agrobotanici Cluj-Napoca, 39(1), 191.

Sundberg, C., Yu, D., Franke-Whittle, I., Kauppi, S., Smårs, S., Insam, H. \& Jönsson, H. (2013). Effects of $\mathrm{pH}$ and microbial composition on odour in food waste composting. Waste Management, 33(1), 204-211.

Tahir, S., \& Marschner, P. (2016). Clay amendment to sandy soil-effect of clay concentration and ped size on nutrient dynamics after residue addition. Journal of Soils and Sediments, 16(8), 2072-2080.

Wang, M., Armour, C., Li, X., Dai, X., Zhu, X., \& Yao, S. (2013). The factorial invariance across gender of three well-supported models: Further evidence for a five-factor model of posttraumatic stress disorder. The Journal of nervous and mental disease, 201(2), 145-152.

Wang, X., Selvam, A., Chan, M., \& Wong, J. W. (2013). Nitrogen conservation and acidity control during food wastes composting through struvite formation. Bioresource technology, 147, 17-22.

Xu, J., Kleja, D. B., Biester, H., Lagerkvist, A., \& Kumpiene, J. (2014). Influence of particle size distribution, organic carbon, $\mathrm{pH}$ and chlorides on washing of mercury contaminated soil. Chemosphere, 109, 99-105. 